\title{
TÜRK PARLAMENTO HUKUKU AÇISINDAN SON ANAYASA DEĞiş̧iKLIKLERI
}

\author{
Dr. Şeref $I B A^{*}$
}

\section{A- PARLAMENTO HUKUKUNA KAVRAMSAL BÍR BAKIŞ}

Son Anayasa değişikliklerinin yasama organının kuruluş ve işleyişini nasıl etkiledił̧ini irdelemek, Türk Parlamento hukuku perspektifinden sözü edilen Anayasa deģişikliklerinin ne anlama geldiğini saptamak ve değerlendirmek için öncelikle, bakış açısıyla ilgili bazı kavramsal konulara değinmek gerekmektedir.

Parlamento hukuku, kapsamı açısından parlamentonun kuruluş ve işleyişine ilişkin doğrudan duizenlemeler getiren hukuk metinleriyle ilgilidir. Bu bağlamda, Anayasanın yasama organıla ilgili hükümleri ve TBMM İçtüzü̇ü, TBMM ile ilgili bazı kanunlar, TBMM kararları, parlamento hukukunun başııca yazılı kaynakları arasındadır.

Parlamento hukuku, Anayasa, Meclis İçtüzüüü ve Meclis ile ilgili kanunlar gibi salt yazılı kaynaklara dayah dar bir hukuk dalı değildir. Öteki hukuk dallarından bazılarında da olduğ gibi, parlamento hukuku açısından yazılı olmayan kaynaklar da büyük öneme sahiptir. Şu halde, Parlamento hukukuyla ilgili henüz yeterli düzeyde olmayan bilimsel çalışmalar, Anayasa Mahkemesi kararları gibi yargısal kararlar ve parlamento teamülleri, Türk Parlamento Hukukunun kaynakları arasmda önemli yer tutar.

Parlamento hukuku, kamu hukukunun bir dalı olan Anayasa hukukunun yapışı ikizi gibidir ve anayasa hukukuyla birlikte düşünülmek zorundadır.

\footnotetext{
- Kamu Yönetimi ve Siyaset Bilimi Doktoru.

TBMM Kanuniar ve Kararlar Müduir Yardımclst-Ankara.

Tel: 42067.78

E-Posta:serefiba@yahoo.com
} 
TEZİÇ de parlamento hukukunu anayasa hukukunun ayrılmaz bir parçası ya da dalı olarak görmektedir.' Gerçekten TEZIÇ, Türkiye de parlamento hukuku alànında bütünü kucaklayan bir araştırmanın henüz yapılmamıș olmasından haklı olarak yakındığı ve Türk Parlamento hukukunun kaynaklarını ortaya koymayı amaçlayan kapsamlı çalışmasında. "Tïrk hukuk dizzeninde, parlamento hukukunun vazll kaynaklart: Anayasa. içüzükler. Kanunlar, Meclis Başkanlik Divan kararlan, Idari diizenleyici işlemleri ve mahkeme kararlari" tespitini yapmaktadır." Bu sıralamaya katılmak olanaklı değildir. Ilkin, TBMM Başkanlık Divanı kararlarının büyük çoğunluğu yasama etkinlikleriyle değil, Meclisin yönetsel işleriyle ilgilidir. Yasamanın kuruluş ve işleyişini doğrudan ilgilendiren kararlar son kertede TBMM Genel Kurulu'nda alındığından, TBMM kararlarını parlamento hukukunun asıl kaynakları arasında saymak gerekmektedir.

Anayasa kuralları ışı̆ında yasama organının kuruluşunu ve işleyişini düzenleyen parlamento kararları niteliğindeki içtüzükler ${ }^{3}$, TBMM kararları içerisinde özel bir konuma sahiptir." Bu bakımdan Anayasa Mahkemesi içtihatlarındaki "İçtüzük Düzenlemesi Niteliğinde" ve "Eylemli İçtüzük Değişikliği veya Eylemli İçtüzùk Kuralı" gibi kavramsallaş̧ırmalar, Meclis kararları içerisinde özel bir kategoriyi oluşturmaktadır.

Parlamento hukukunun yazılı kaynakları içerisinde en temel konumda Anayasa yer alır. Anayasanın "Cumhuriyetin Temel Organlar" başlıklı üçüncü kısmının birinci bölümü "yasama" başlığını taşımakta ve yasama organının kuruluş ve işleyişiyle ilgili kurallar içermektedir. Bununla birlikte, Anayasanın başka maddelerinde de yasamayı ilgilendiren düzenlemelere rastlamak olanaklıdır.

\footnotetext{
' Erdoğan TEZlç (1980). Türk Parlamento Hukukunun Kaynakları ve İlgili Anayusa Mahkemesi Kararları, Ístanbul: Fakü]teler Matbaası., s.15.

2 TEZIÇ (1980), s.12; BAKIRCI da, bu görüşlere katulır görünmektedir.

Bkz.Fahri BAKIRCl (2000). TBMM'nin Çalışma Yöntemi ,Ankara. İnge Kitabevi. I. Baskı, s.19-37

${ }^{3}$ Şeref iBA (2001), Türkiye'de Meclis Başkanlığı ve Başkanlık Divanı. Ankara: Nobı Yayın Dağım. Yayın No:270.1.Basım. s. 23-24

" Ergun ÔZBUDUN (1979), "Parlamento Kararları ve Yasama Meclislerinits İçtüzisklerì". A.Ü. Hukuk Fakültesi Dergisi. C.XXXV1., Sayı:1-4.s.3-26.

${ }^{5}$ Anayaşa Mahkemesi, Meclis çalışmalarıyla ilgili yöntem ve esaslara ilışkin TBMM Karariarını "iççüzük düzenlemesi njteliłơnde" görmektedir. Bkz. Anayasa Mahkemesi Kararlar Dergisi, E.199127. K.1991/50. 12.12. 1991, C.27/2, s.681-703. Yüksek Mahkene bazı TBMM kararlarını ise "cylemli içrüzük kuralı" kavramı yardımıylił Anayaısal denctim kapsamsnda değgerlendirmektedir. Bkz. Anayasa Mahkemesi Kararlar Dergisi. E. 1942/26. K. 1992/48, 17.9.1992. C.28. s.548.
} 


\section{B- 4709 VE 4720 SAYILI KANUNUNLARLA YAPILAN ANAYASA DEĞİ̧̇iKLIİKLERİ}

Yaklaşık 19 yılđır uygulanmakta olan 1982 Anayasası bugüne kadar toplam yedi kez değişikliğe ugramıştır. ${ }^{6} 1982$ Anayasasındaki değişikliklerin en kapsamlısı olan altıncı Anayasa deģişikliklerine ilişkin kanun teklifinin mimarı, Partiler arası Uzlaşma Komisyonudur ${ }^{7}$. Uzlaşma Komisyonu tarafından kabul edilen metin, biri geçici madde olmak üzere 39 maddeden oluşmaktaydı. Sözü edilen taslak metin öncelikle tüm milletvekillerine dağıtılmıştır.

Anılan metin, Istanbul Milletvekili Bülent Ecevit, Osmaniye Milletvekili Devlet Bahçeli, Rize Milletvekili Mesut Yılmaz ile 288 Milletvekili'nin imzasıyla Kanun Teklifi olarak TBMM Başkanlığına sunulmuştur. Anılan kanun teklifi 38 madde ve bir geçici maddeden oluşmaktadır. Kanun Teklifinin Anayasa Komisyonundaki görüşmeleri sırasında, bazı ibare, fıkra ve maddelerde değişiklik ya da ilaveler yapılmış ancak Anayasa Komisyonu" tarafundan Teklifin geneliyle ilgili kapsamlı bir değişiklik yapılmadan oybirliğiyle kabul edilmiştir. ${ }^{10}$

TBMM tarafindan kabul edilen 3.10.2001 tarihli ve 4709 sayıl Türkiye Cumhuriyeti Anayasasının Bazı Maddelerinin Değiştirilmesi Hakkında Kanun, 35 madde ve bir geçici maddeden oluşmaktadır." Anayasa Komisyonunun kabul ettiği metinde yer alan üç madde ${ }^{12}$ ikinci görüşme sonunda Anayasa deģişiklikleri için öngörülen sayıda kabul oyuna ulaşamadığı için TBMM Genel Kurulu tarafından reddedilmiştir. Dolayısıyla, metindeki madde numaraları buna göre yürütülmüş̧ür.

\footnotetext{
${ }^{\circ}$ Anılan değişiklikler sırasıyla; 1)-17.5.1987 tarihli ve 3361 sayıı kanunla, 2)-8.7.1993 taribli ve 3913 sayıl kanunla, 3)-23.7.1995 tarihli ve 4121 sayıl kanunla, 4)- 18.6 .1999 tarihli ve 4388 sayılı kanunla, 5)- 13.8 .1999 ve 4446 sayılı kanunla, 6)- 3.10.2001 tarihli ve 4709 sayıl kanunla, 7)-21.11.2001 tarihli ve 4720 sayılı kanunla gerçekleştirilmiştir.

${ }^{7}$ Meclis Başkanvekillerinden birinin başkanlığında çalışan Uzlaşma Komisyonu, siyasi parti gruplarının eşit sayıda temsili ilkesine göre ikişer temsilciden oluşmaktadır. Resmi-hukuki bir dayană̆ı bulunmayan bu komisyon, siyasi parti gruplanı arasında uzlaşmaya varılan konularda Anayasa değişikliği teklif taslakları hazırlayan özel görevli partiler arası resmi olmayan bir girişimci kurul olarak işlev görmektedir. Bu bağlamda, söz edilen komisyonda, siyasi parti gruplarından gelen Anayasa değişikliği önerileri ele alınmakta ve varsa görüş ayrılıklan giderilerek uzzerinde uzlaşma sağlanan metinler oluşturulmaktadır.

" TBMM,S. Sayısı: 737. Dönem:21, Yasama Yılı:3, s. 1-8.

"Söz konusu Kanun teklifiyle ilgili Anayasa Komisyonu görüşme tutanaklanı için bkz. TBMM Arşivi, s. [-81.

I" TBMM, S.Sayısı: 737, Dönem: 21. Yasama Yllı: 3. s.8-24.

" Resmi Gazete, 17.10.2001, sayı:24556 (mükerrer), s.1-6.

12 Teklifte yer alan; Anayasanın 76. maddesinde değişiklik yapan çerçeve 27. madde; Anayasanın 83. maddesinde değişiklik yapan çerçeve 28. madde; Anayasanın 90 . maddesinđđe değişiklik yapan çerçeve 32. madde TBMM Genel Kurulunca reddedilmiştir.
} 
Son değişiklik demetinde parlamento hukukuyla doğrudan ilgili altı maddede çeşitli ölçülerde değişiklik yapılmıştır. Bunlar; af ilanı (m.87), Milletvekillerinin ödenek ve yolluklan (m.86), Cumhurbaşkanının kısmi geciktirici veto yetkisi (m.89), TBMM Başkanının seçimi (m.94), Meclis: Soruşturması (m.100), Seçim Kanunlarmda değişiklik (m. 67). Sözü edilen maddelerde yapılan değişiklikler ayrı ayrı gözden geçirildikten sonra, bu değişikliklerin parlamento hukukuna etkileri açısından genel bir değerlendirme yapılabilir.

\section{1-Ödenek ve Yolluklar}

TBMM İçtüzüğü tarafından yasama organı üyelerine sağlanan malj haklar ile yasama çalışmaları arasında -özellikle devamsızlık açısındandoğrudan ilgi kurulmuştur. ${ }^{13} \mathrm{Bu}$ nedenle, TBMM üyelerinin ödenek ve yolluklarıyla ilgili düzenlemeler, parlamento hukuku kapsammda ele almabilir.

Anayasa Komisyonu tarafindan tekliften aynen kabul edilerek TBMM Genel Kuruluna sunulan metinde Çerçeve 29. Madde ile Anayasanın "Ödenek ve Yolluklar" başlıklı 86. maddesi şöyle düzenlenmişti;

" MADDE 29.-Türkiye Cumhuriyeti Anayasasınu 86 na maddesinin birinci fikrasimn birinci cümlesi "Türkiye Bïyilk Millet Meclisi ïyelerinin odenek, yolluk ve tazminatlart, sosyal haklart ve emeklilik islemleri kanunla düzenlenir." Şeklinde değiştirilmiş; fikranm sonuna "Türkiye Bïyük Millet Meclisi üyeleri ile bunlarm emeklileri T.C. Emekli Sandiğ ile ilişkilendirilirler ve üyeliği sona erenlerin istekleri halinde ilgileri devam eder." Ibaresi eklenmiş ve aynt maddenin ikinci fikrastnda geçen "sosỵal güvenlik kuruluşlarl" ibaresi "T.C. Emekli Sandrğı" olarak değişstirilmiştir."

Böylece, TBMM üyelerinin ödenek, yolluk ve emeklilik konularının kanun ile dïzenlenmesi öngörüilüyor: Milletvekilleri ile emeklilerinin Emekli Sandığı ile ilişkilendirilmesi zorunlu hale geliyordu. Anılan maddenin teklifteki (Uzlaşma Komisyonu tarafından benimsenen) biçimine, "ve tazminatları, sosyal hakları" ibaresi Anayasa Komisyonu tarafindan eklenmişti. ${ }^{14}$

13 153, ve 154. maddeler: Bkz. Türkiye Cumburiyeti Anayasası ve Türkiye Buyuik Millet Meclisi İçtiizuğü. , 2001. Ankara, TBMM Basımevi, s. 89-90.

${ }^{14}$ Anayasa Komisyonu Raporu; S.Sayısı; 737, Dönem:21. Yasama Yl1ı:3, s.7. 
Ancak bu madde, TBMM Genel Kurulundaki ikinci görïşmede verilen bir önergenin kabul edilmesiyle yeni baştan düzenlenmiştir. Kabul edilen önerge ${ }^{15}$ doğrultusunda maddenin kanunlaşan biçimi şöyledir:

"MADDE 27.-7.11.1982 tarihli ve 2709 sayll Tïrkiye Cumhuriyeti Anayasasını 86 ncı maddesinin başlığt ile birinci fikrast aşağıdaki şekilde. ikinci fikrasında geçen "sosyal güvenlik kuruluşlarl" ibaresi de "Türkiye Cumhuriveti Emekli Sandığı" olarak değiştirilmiştir.

\section{7. Ödenek, yolluk, emeklilik ve sosyal haklar}

Tïrkiye Büyük Millet Meclisi üyelerinin ödenek ve yolluklar ile sosyal hakları, emeklilikleri ve tazminatlart özel kanunda dïzenlenir. Ödeneğin tutarı, en yüksek Türkiye Cumhuriyeti Emekli Sandığt iştirakçisinin görevde iken almakta olduğu miktardan, yolluk tutar ödenek miktarintn yarıstndan, bağlanacak emekli aylikları da bunların toplaminin yarısindan az olamaz.

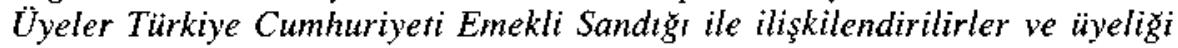
sona erenlerin istekleri halinde Türkiye Cumhuriyeti Emekli Sandiğt ile ilişileri devam eder."

4709 sayılı Kanunun sadece çerçeve 27. maddesi $^{17}$, Cumhurbaşkanı tarafından Anayasanın 175. maddesi uyarınca halkoylamasına sunulmuş; aynı kanunun geri kalan maddeleri Cumhurbaşkanı tarafından Resmi Gazetede yayımlanarak yürürlüğe sokulmuştur. Cumhurbaşkanı'nın referandum kararı, Anayasanın 175. maddesinin nasıl anlaşılması

\footnotetext{
${ }^{15}$ Sözü edilen önerge, TBMM Genel Kurulunda ikinci görilşme sırasında verilmiş: yapılan görüşmenin ardından gizli oylama sonucu kabul edilmiştir. Daha sonra ise, madde kabul edilen önerge doğrultusunda yeniden gizli oya sunularak kabul edilmiştir. Dolayısıyla, anılan mađđdeyi yeniden düzenleyen önerge iki kez oylanmış olmasına karşın bir kez görüşülmüştür. Bu bakından, söz konusu madde; Anayasanın 175. maddesindeki "Anayasanın değiştirilmesi hakkındaki teklifler Genel Kurulda iki defa görüşülür." Kuralına şekil yönünden aykırı biçimde kanurlaşmıştır.

${ }^{16}$ Bu madde Cumhurbaşkanı tarafından halkoyuna sunulmuşıur.( 23.5.1987 tarihli ve 3376 numaralı Anayasa Değişikliğinin Halkoyuna Sunulması Hakkında Kanun'un 2. maddesi uyarınca, halkoylamasının ilgili Anayasa değişikliği kanununun Resmi Gazetede yayımını takip eden yüz yirminci günden sonraki ilk Pazar günï (17.2.2002) yapiłması gerekmektedir. Bkz. Resmi Gazete: 22.10 .2001 , sayı:24561 (mükerrer)

${ }^{17}$ Söz konusu maddeyle ilģili ikinci görüşme sonucunda yapılan gizli oylamanın sonuçıarı şöyledir:

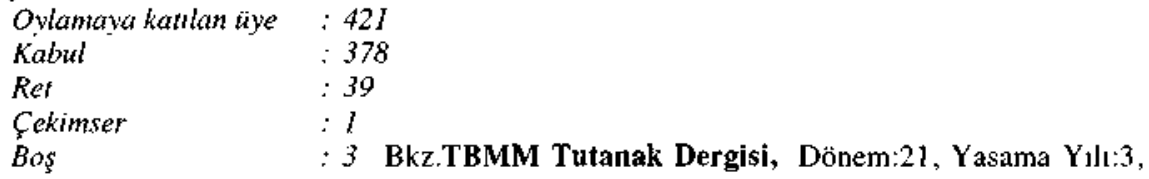

B. 3, 3.10.2001.
} 
gerektiğiyle ilgili hukuki tartışmalara yol açmıştır. ${ }^{1 *}$ Gerçekten de Cumburbaşkanlığının TBMM Başkanltğı'na gönderdiği konuya ilişkin yazıda ${ }^{19}$, kamuoyundaki tartışmalara ışık tutan ve Cumhurbaşkanı tarafından yapılan uyģulamanın gerekçelerini sıralayan bir yaklaşım sergilendikten sonra sonuç değerlendirmesi yapılmaktadır.

Bu bağlamda, Anayasanm 175. maddesinin dördüncü fikrası uyartnca, TBMM ïye tamsayısının beşte üçü ile ya da üçte ikisinden az oyla kabul edilen Anayasa değ̣işikliğine ilişkin kanunun Cumhurbaşkanınca TBMM'ye geri gönderilmemesi durumunda halkoyuna sunulmasının zorunlu olduğu vurgulanmaktadır. 175. maddenin beşinci fıkrası ise, Cumhurbaşkanının takdirine bağlı bir düzenleme öngörmüştür. Bu ftkra ile, doğrudaun ya da Cumhurbaşkanının geri göndermesi üzerine, TBMM üye tamsayısının üçte iki çoğunluğu ile kabul edilen Anayasa değişikliğine ilişkin Kanun ya da gerekli görälen maddelerinin Cumhurbaşkanı'nca halkoyuna sunulabilmesinc olanak tanınmıştır.

Cumhurbaşkanlı̆̆ımın yazısında Anayasanın 175. maddesinin beşinci ve yedinci fıkralarıyla ilgili şu degerlendirmelere yer verilmiştir;

“...Görilldirğii gibi, maddenin beşinci fikrasında Cumhorbaşkam'na. gerekli görmesi durumunda, Anayasa değişikliğine ilişkin yasanm tïminii. maddelerinden kimilerini ya da bir maddeyi halkoylamasina simabilme. yetkisi verilmistir.

Öte yandan, aym maddenin yedinci fikrasmda, Tïrkiye Biryïk Millot Meclisi'nin. Anayasa değişikliklerine ilişkin yasalarm kabulii sirasmda, bu yasamn halkoylamastna sunulmast durumunda. Anayasanm de ğiştirilon kurallarindan hangilerinin birlikte, hangilerinin ayn ayr oylanacağın da karara bağlayacă̆̆ belirtilmiştir...

Bu nedenle, 175. maddenin beşinci ve yedinci fikralarmm birlikte yorumlanması ve Cumhurbaşkant ve Tïrkiye Büyïk Millet Meclisi'ne verilen yetkilerin birbirini engellemeyecek biçimde kullanlmast en doğru ve Anayasaya en uygun çözïm olacaktor. Dolaytstyla, Cumhurbaskaminm Anayasay değistiren yasantn madde ya da maddelerini halkoyuna summa

\footnotetext{
"Ulkenin ckonomik kriz içinde bulunduğu bir dönemde. Anayasanın 86 . maddesiyle ilgili yapılacak referandumun. ekonomiye yen bir mali külfet yaratacăğ yönïndeki tartışmalar

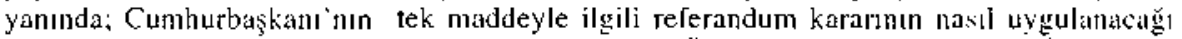
konusundaki hukuki tartışmalar gündeme gelmiştir. Örneğin bkz. Erdoğăn TEZİç ve Işin ÇELEBİ ilc Söyleşi. Cumburiyet, 21.10.2001 s.12.

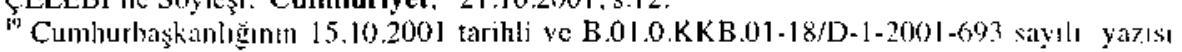
için blæ.TBMM Tutanak Dergisi. Dönem:21, Yasama Yıı:4. Birleşim; 7, 16.11 .2001.
} 
yetkisi karşıstnda, Tïrkiye Büyük Millet Meclisi'nin yetkisi, Anayasantn değiştirilen kurallarından hangilerinin birlikte, hangilerinin ayr ayr oylanacă̆ın belirtmekten ibarettir. ${ }^{20}$

Cumhurbaşkanı'nın yazısında vurgulandığı gibi, 4709 sayılı Anayasa değişikliğine iliş̧in Kanunun 35. maddesinde yer alan.

"Bu Kanun, yayımı tarihinde yürürlüğe girer ve halkoylamasına sunulması halinde tümïyle oylanır." hükmü, Anayasa değişikliğine ilişkin kanunun birden fazla maddesinin halkoyuna sunulması durumunda anlam kazanarak; halkoyuna sunulan maddelerin tümünün birlikte oylanmasını saglayacaktır. Doktrinde, 175. maddenin 3.,4. ve 5. fikralarının birlikte ele alındığında Anayasa değişikliklerinde biri "zorunlu", öteki "ihtiyari" olmak üzere iki tür halkoylaması ayrımı yapılmaktadır ${ }^{2 !}$ Buna göre, Cumhurbaşkanı, TBMM'nde üye tamsayısının beşte üçü ile üçte ikisi arasında bir çoğunlukla kabul edilmiş olan Anayasa deģişikliğini, eğer bir daha görüşülmek üzere Meclise geri göndermiyorsa halkoyuna sunmak zorundadır. Buna karşın, Meclisin ister doğrudan, ister geri gönderilmesi üzerine, üye tamsayısının ucçte ikisi veya daha fazlası bir çoğunlukla kabul ettiği bir Anayasa deģişikliğini ise Cumhurbaşkanı, dilerse halkoyuna sunacak, dilerse Resmi Gazetede yayımlayıp yürürlüğe girmesini sağlayacaktır.

ONAR'a göre, Anayasanın 175. maddesinin 5. fıkrası gereğince, Cumhurbaşkanı, en az üçte iki çoğunlukla kabul edilmiş bir Anayasa değişikliğini halkoyuna sunmak isterse, bu takdirini kanunun tüm maddeleri için kullanmak zorunda değildir; dilerse, bir ayrım yapıp , kanunun sadece bazı maddelerini halkoyuna sunabilir, öteki maddeleri ise Resmi Gazetede yayımlayıp yürürliiğe girmesini sağlayabilir..$^{22}$ Gerçekten de Anayasanın 175. maddesinin 5. fıkrası uyarmca, Anayasa değişikliklerine ilişkin olarak Cumhurbaşkanına 1982 Anayasası ile verilmiş olan geniş yetkiler içinde, Anayasa değişikliği kanunlarıyla ilgili kısmi geciktirici veto yetkisi tanınmış bulunmaktadır.

Cumhurbaşkanı'nın 4709 sayılı Anayasa değişikliğine ilişkin kanunun çerçeve 27. maddesiyle Anayasanın 86. maddesinde yapılan düzenlemeyi doğrudan halkoyuna sunması üzerine, halkoylaması sürecini durdurmak üzere girişimler ortaya çıkmıştır. Bu bağlamda, Partiler arası Uzlaşına

\footnotetext{
2" TBMM Tutanak Dergisi, Dönem:21, Yasama Yılı:4. Birleşim; 7, 16.11.2001.

${ }^{21}$ Erdal ONAR (1993), 1982 Anayasasında Anayasayı Değiştirme Sorunu, Ankara, s.95100. Ayrıca bkz. Cem EROĞUL (1974). Anayasayı Değiştirme Sorunu, Ankara, AÜSBF Yaytn No:871.

" ONAR (1993). s. 100.
} 
Komisyonu toplanarak, Anayasanın 86. maddesiyle ilgili tek maddelik yeni bir Anayasa değişikliği teklifine temel olmak üzere yeni bir metin hazırlayarak milletvekillerine sunmuştur. Uzlaşma Komisyonu'nca hazırlanan taslak 313 milletvekili tarafından imzalanarak Anayasa değ̣işikliği teklifi olarak 26.10.2001 tarihinde TBMM Başkinlığıa sunulmuştur.

Osmaniye Milletvekili Devlet Bahçeli ve Rize Milletvekili Mesut Yllmaz ile 311 milletvekilinin imzasını taşıyan (2/818) Esas Numaralı Kanun teklifinin çerçeve 1. maddesiyle Anayasanın 86. maddesi şöyle dïzenlenmiştir:

"7.11.1982 tarihli ve 2709 sayll Türkiye Cumhuriveti Anayasasmm 86 nct maddesinin birinci fikrasın birinci cümlesi "Türkiye Bïyiik Millet Meclisi iiyclerinin ödenek, yolluk ve emeklilik işlemleri kanunla diizenlenir" şeklinde değiştirilmiş; fikranin sonuna "Tïrkiye Büyük Millet Meclisi üyeleri ile bumlarm emeklileri T.C.Emekli Sandı̆̆ ile ilgilendirilirler ve ïyeliği sona erenlerin istekleri halinde ilgileri devam eder" ibaresi eklenmis ve aym maddenin ikinci fikrasmda geçen "sosyal gävenlik kuruluşlart" ibaresi "T.C.Emekli sandı̆̆̆" olarak de ğiştirilmiştir."

Teklifin madde gerekçesinde, milletvekillerinin emeklilik işlemlerinin yasayla düzenlenmesi gereksinimine Anayasal dayanak sağlandığı; Emekli Sandığı ile ilgilendirilmesiyle de farklı sosyal güvenlik kuruluşları ile ilgi kurulmasindan doğan eşitsizliğin giderilmesinin amaçlandığ belirtilmektedir. ${ }^{\text {?. }}$

Söz konusu Anayasa değişikliği teklifinin birinci görüşmesi. TBMM Genel Kurulunun 6.11.2001 tarihli 16. Birleşiminde; ikinci görüşmesi ise 21.11.2001 tarihli 23. Birleşimde yapılmış ve kabul edilmiştir. 21.11.2001 tarihli ve 4720 sayıl Türkiye Cumhuriyeti Anayasasının Bir Maddesinin Değiştirilmesi Hakkında Kanunun çerçeve 1. maddesiyle Anayasanın 86. maddesi yeniden düzenlenmiştir.

\section{2- Af İlanı}

3.10.2001 tarihli ve 4709 sayılı Türkiye Cumhuriyeti Anayasıısını Bazı Maddelerinin Değiştirilmesi Hakkında Kanunun çerçeve 28. maddesiyle, Anayasanın TBMM'nin görev ve yetkilerini genel olarak sayan 87. maddede değişikliğe gidilmiştir. Buna göre, Anayasanın 87. maddesinde geçen "Anayasamn 14 incii maddesindeki fillerden dolayn hïkïm giyenler harig

\footnotetext{
${ }^{23}$ Analyasá Komıxyonu Raporu. S. Sayısı: 753, Dönem:21. Yasama Y1lı:4.
} 
olmak üzere" ibaresi kaldırılmıştır. Böylece, Meclisin af ilanı yetkisine konu yönünden Anayasa ile getirilmiş olan sınırlamalar kaldırılmış; Anayasanın "Temel hak ve hürriyetlerin kötüye kullanılmaması" başlıklı 14 . maddesindeki fuillerden dolayı da TBMM'ne genel ve özel af ilan edebilme olanağı tanınmıştır.

Aynı madde ile, TBMM'nin genel ve özel af ilanına Türkiye Büyük Millet Meclisi üye tamsayısının beşte ùç çoğunluğunun oyuyla karar verebilmesi kuralı getirilmiştir. TBMM'nin genel ve özel af ilanı yetkisiyle ilgili olarak Anayasanın 14. maddesiyle ilgili kayıt kaldırıldığından Meclisin yetki alanı genişlemiştir. Öte yandan, genel ve özel af ilanı kararı alabilmek için beşte üiç nitelikli çoğunluk koşulu getirilmesi, parlamento hukukumuz açısından yeni bir şekil kuralı olarak karşımıza çıkmakta ve TBMM'nin af ilanı kararı alabilmesini büyük ölçüde güçleştirmektedir.

Ayrıca, 4709 sayılı Kanunun Geçici Maddesi ${ }^{24}$ uyarınca, TBMM'nin genel ve özel af ilanıla ilgili olarak yapılan değişikliğin, bu kanunun yürürlük tarihinden önce, Anayasanın 14 ûncü maddesindeki fiilleri işleyenler hakkında uygulanmayacağı öngörülmüş̧ür.

\section{3- Seçim Kanunlarıyla İlgili Düzenlemeler}

4709 sayılı Kanunun çerçeve 24. maddesiyle getirilen düzenleme şöyledir: "Türkiye Cumhuriyeti Anayasasinin 67 inci maddesinin beşinci fikrasına "askeri öğrenciler", ibaresinden sontra gelmek ïzere "taksirli suçlardan hüküm giyenler hariç" ibaresi eklenmiş ve "bulunan tutuklularn seçme haklarm kullanmalarında", ibaresi "oy kullantmast ve "şeklinde de ğiştirilmiş ve maddeye aşă̆̆daki son fikra eklenmiştir.

Seçim kanunlarında yaptlan değişiklikler, yürürlüğe girdiği tarihten itibaren bir yl içinde yapilacak seçimlerde uygulanmaz."

Böylece, taksirli suçlardan hüküm giyenler oy kullanma yasağı dışına çıkarılmış ve Ceza infaz kurumları ve tutukevlerinde oy kullanılması konusunda Yüksek Seçim Kurulu’na verilen göreve açıklık getirilmiştir.

Seçim kanunlarında yapılan deģişikliklerin yürürlüğ̈ü konusunda öngörülen kayıt, seçim kanunları yoluyla sağlanabilecek siyasal avantajların ve istismarların önlenmesini amaçlamaktađır.

\footnotetext{
${ }^{24} 4709$ numaralı Kanunun Geçici Maddesinin B Bendi şöledir: "B) Bı Kanuntın 28 inci maddesi ile Anavasanm 87 inci maddesinde yapulan değişiklik, bu kanunun yürürlük tarihinden önce. Anavasann 14 üncu maddesindeki filleri işleyenler hakkutda aygulanmaz."
} 
Partiler arası Uzlaşma Komisyonu tarafından hazırlanan ve Meclis Başkanlığına sunulan Anayasa Deģişikliği Teklifinde, Anayasanın 67. maddesinin son fikrasinın ${ }^{25}$ da yürürlükten kaldırılması öngörülmüştü. Ancak bu Anayasa Komisyonu tarafından benimsenmemiştir. Teklifte, Temsilde adalet ve yönetimde istikrar ilkelerinin bağdaştırımasının son derece zor olduğu ve oldukça soyut olan bu ilkelerin seçim kanunlarında köklü değ ş̧iklikler yapılmasını güçleştirdiği için kaldırılması gerektiğ̣ gerekçe olarak ileri sürüilmüştìi. ${ }^{26}$

Yeni düzenlemenin, parlamento hukukumuz açısından önem taşıyan yönü, seçim kanunlarıyla ilgili olarak genel seçime bir yıl kala yapılacak deģişikliklerin yürürlüğünün bir bakıma gelecek seçimlere kadar ertelenmesidir. Ancak getirilen bu yeni düzenlemenin Anayasa değişikliğinin yürürlü̆ğe girmesinden sonra yapılacak ilk genel seçinde uygulanmayacağı Geçici Maddenin A Bendi ${ }^{27}$ ile kurala bağlanmıştır.

\section{4- Cumhurbaşkanınca Kanunların Yayımlanmasının Kısmen Uygun Bulunmamast}

4709 sayılı Kanunun çerçeve 29 . maddesi ${ }^{2 *}$ ile kanunların Cumhurbaşkanı tarafından yayımlanmasını düzenleyen 89 . maddede önemli bir değişiklik yapılarak. Cumhurbaşkanına kanunları kısmen, başka bir deyimle bir kanunun bir veya birkaç maddesini bir daha göruiş̧iilmek üzere Meclise geri gönderme yetkisi tanunmıştır. ${ }^{29}$

\footnotetext{
"S Sözï edilen likra şöyledir: "Seçim kanunlan, temsilde adalet ve vonetinde isthrot

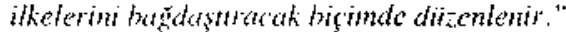

Anayasa Komisyonu Raporu, S. Sayısı: 737, Dönem:21, Yasama Yıì:3. 5.6.

${ }^{27}$ Geçici Maddenin A Bendi şöyledir: "A) Bu Kanumun 24 ïncii maddesi ile Anarusamm 67

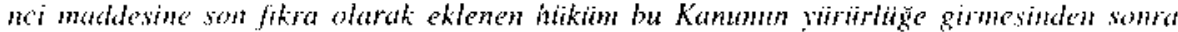
yaplacuk in genet seçimelo uygulanma:."

${ }^{20}$ Çerçeve 24. maddcye Anayasanm 89. maddesinin son cümlesinden ance gelmek üzar

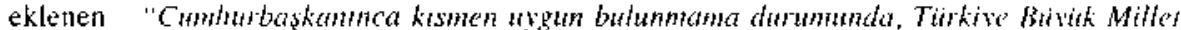
Medisi sadece mgan buhmmayan naddeleri görisebilir." Biçimindeki cünle. son cümleden sonra gelmek üzere eklenmeliydi. Çerçeve maddeyle. Anayasanın 89. maddesine yúpulan gönderme. sooz konusu Anayasa kuralını, amaca uygun olmayan yorumlara ve uygulamatara

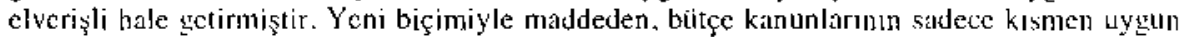
bulmana kurălndı istisna tutulduğu: tümüyle bir datha görüşülmck ijzere TBMM 'ne geri gönderilebileceği anlàmı doğmaktadır.

"Madde metni soyledir:"Tärkye Camhuriveti Anawasasm 89 unch maddesimm ikind

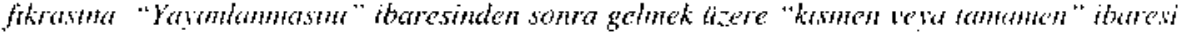

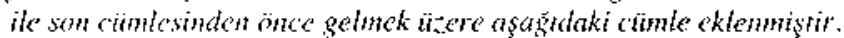

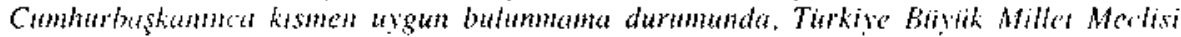
sadece argun butammatin maddeleri görissebilir."
} 
Cumhurbaşkanına böyle bir Anayasal yetki verilmesinden amaç, TBMM'de uzun çalışmalar sonucu kabul edilen ve görece uzun kanunların bir veya birkaç maddesi nedeniyle yeniden ve tümüyle bir daha görüşülmek izere Meclise geri gönderilmesinden kaynaklanan zaman kaybını önlemektir. Ancak, bu deģişiklik, yasama organının hızlı ve verimli çalışması için olumlu yönde gerçekleştirilmiş bir yenilik olmakla birlikte, parlamento hukukumuzda yeni sorunlara yol açabilecek niteliktedir.

İlkin, Cumhurbaşkanı tarafından bir kanunun yayımlanmasının kısmen uygun görülmemesi durumunda, geri kalan uygun buldugu madde ve/veya maddeleriyle birlikte kanunu tümüyle Meclise geri göndermesinin zorunlu olup olmadığı açık değildir. Son Anayasa değişiklikleriyle, Anayasa hukukumuza yeni kazandırılan Cumhurbaşkanınca kanunların kısmen geri gönderilebilmesi yetkisi, en çok da kısmen geri göndermenin, bir kanunun gerek gördüğünde bölerek geri gönderilebilmesi mi yoksa, bir daha görüşülmek üzere Meclise geri gönderilen bir kanunun geri gönderme gerekçesinin doğrudan doğruya belli madde veya maddelerle (hangi maddeler yüzünden geri gönderildigyi) ilintilendirilmesi ve dolayısıyla da parlamentoya sadece ilgili maddeleri yeniden görüş̧ebilme olanağı tanınması anlamına mı geldiği konusu, yeterince net değildir.

Cumhurbaşkanı tarafından birinci yolun benimsenmesi dolayısıyla da, bir daha görüşülmek üzere Meclise geri gönderilen maddeler hariç tutularak kanunun geri kalan maddelerinin Resmi Gazetede yayımlanması durumunda, altıncı anayasa değişikliğiyle Cumhurbaşkanına verilen kısmi geciktirici veto yetkisi, parlamenter rejimin özüyle bağdaşmaz sonuçlara yol açabilir. Bu durumda, yürütmenin sorumsuz kanadı konumundaki Cumhurbaşkanının yetkileri, yasama organı aleyhine olarak genişlemektedir. Bu genişleme, aynı zamanda, siyasal rejimimizin yarı başkanlık sistemine doğru kayması anlamına gelecektir.

Böyle bir durumda, Cumhurbaşkanı tarafından kısmen geri gönderilen bir kanunun geri kalan maddeleri yayımlanarak yürürlüğe gireceğinden "yarım kanunların" yürürlüğüune tanık olunacaktır. Kanun tekniği açısından tüm maddeleriyle belli bir bütünlüğe sahip olan bir kanunun, Cumhurbaşkanı tarafundan ayıklanarak sadece belirli maddelerinin Resmi Gazetede yayımlanması ve dolayısıyla da bazı maddelerinin bir daha görüşülmek üzere Meclise geri gönderilmesi hukuk sistemimizde sorunlar doğurabilecek bir konudur. Örneğin, Cumhurbaşkanı tarafından bir veya birkaç maddesi geri gönderilen kanunun TBMM tarafından yeniden görüşüilmemesi ya da hiç görüşülmemesi olanaklıdır. Bu durumda, yarım olarak yürürlïge girmiş kanun, sürekli yarım olarak uygulanmak zorunda kalacaktır. 
Cumhurbaş̧anının bir daha görüşülmek üzere Meclise geri göndereceğj maddelerin kanunun bütünlüigüunü etkileyebilecek madde veya maddeler olması durumunda kanunun yürürlüğe girmesiyle ilgili sorunlar yaşanması da olanaklı görünmektedir. Örneğin, bir kanunda, bazı maddelerin yayımından altı ay sonra yürürlüğe gireceğini kurala bağlayan bir yiurürlük maddesinin gönderme yaptığı maddenin Cumhurbaşkanı tarafından Meclise geri gönderilmesi durununda ortaya çıkan hukuki sorun nasıl çözülecektir? Bu bakımdan, Meclisin "yasa yapma" yetkisi önünde yeni ve ciddi bir engel oluşmaması için Cumhurbaşkanımın kısmi geciktirici veto yetkisini kullanırken kanunun bütünlüğü ve yürürlüğü açısmdan dikkatli bir tutum sergilemesi ve kısmen geri gönderme hallerinde, yayımlanmasını uygun gördïğỉ geri kálan maddeleri yayımlamaması gerekir. Aksi halde, 1982 Anayasası ile Cumhurbaşkanına verilen geciktirici veto yetkisi bazı durumlarda "mutlak veto" ya da "önleyici veto" yetkisine đönüşebilecektir.

Kısmen geri göndermeyle ilgili değişiklik yüriislïğe girdikten sonraki ilk uygulama. "Devlet Güvenlik Mahkemelerinin Kuruluş ve Yargilana Usulleri Hakkinda Kanun, 18.11.1992 tarihli ve 3842 sayli Kanun ile Çkar Amaçh Sus Örgütleriyle Mücadele Kanununda Değişiklik Yapilmasma Dair" 4719 sayılı Kanunla ilgili olmuştur ${ }^{\text {3i) }}$. Cumhurbaşkanı, anılan kanunun 1,2,3, ve Geçici 1. maddelerini Anayasanın 89. maddesi uyarınca bir daha görüşülmek üzere TBMM'ne geri göndermiş; ancak, yerinde bir uygulamayla, kanunun geri kalan maddelerini yayımlamamıştır. ${ }^{31}$

Söz konusu kanunun görüşmelerine başlanmadan önce, Anayasannn 89 . maddesine yeni düzenlemeyle eklenen "Cumhurbaşkaninca kismen uygun bulunmama durumunda. Tükive Bïyük Millet Meclisi sadece "rgun bulummavan maddeleri görüşebilir." Biçimindeki cümlenin nasıl anlaşılması gerektiği konusundaki Başkanlık açıklamasının ardından TBMM İçtiuzügüünün 63. maddesi ${ }^{32}$ uyarınca Genel Kurulda usul görüşmesi açılmıştır. Yapılan görüşmeler sonucunda Başkanlık açılaıması doğrultusunda, TBMM'nin kismen ya da tümüyle görüşmek konusunda tercih hakkı bulunduğu ve bu seçimini, işin başlangıında karar alarak ortaya

\footnotetext{
: Böylece, 14.11.1962 tarihinden bugüne kadar cumburbaşkanlarınca bir daha ģörüşüłmek üzere TBMM'ne geri gönderilen kánun sayısı 97 'ye ulaşmıştır. Ancak sonuncusu kısmen geri göndemenin ilk ve lek ömeğini oluşırturnaktadır.

"în Cumburbaşkath Ahmet Necdet Sezer'in geri gönderme gerekçesi için bkz. TBMM Tutanak Dergisi, Dönem:21, Yasama Yılı:4. B. 32,6.12.2001. s.1-16.

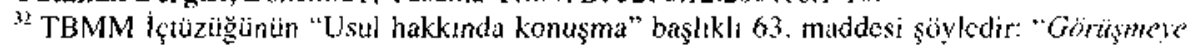

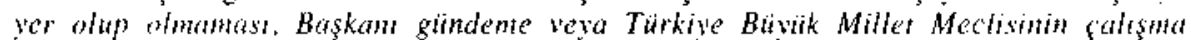

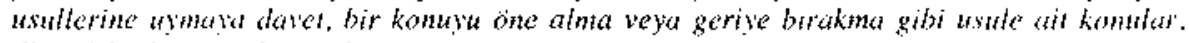
diger işlerdent ince konuşular.

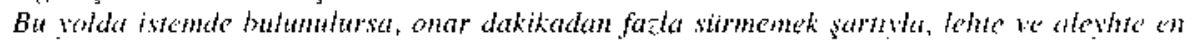
gok ikişer hişige sös verilit.

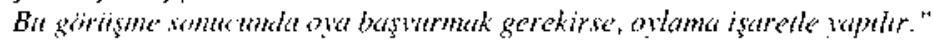


koyması gerektiği benimsenmiştir. Usul görüşmeși sonunda yapılan işaretle oylama üzerine alınan TBMM kararıyla ilgili kanunun sadece Cumhurbasskanınca geri gönderilen maddelerinin yeniden göruş̧ülmesi kabul edilmiştir. $^{33}$

\section{5- TBMM Başkanının Seçimi}

3.10.2001 tarihli ve 4709 sayılı Kanunun çerçeve 30. maddesi ile Anayasanın 94. maddesinde, TBMM Başkanı seçimi için öngörülen süreler kısaltılmıştır. Buna göre Başkan seçiminin Mechisin toplandığı günden itibaren 10 gün içinde tamamlanması gerekmektedir. Değişiklik öncesinde bu süre toplam 20 gün olarak diuzenlenmişti. 20 günlük sürenin 10 günü aday gösterme için kalan 10 günü ise Başkan seçimiyle ilgili turlar için ayrılmıştı.

Anayasanın 94. maddesinde Başkan adaylığı için öngörülen sürenin 10 günden beş güne düşürülmüş olması yerinde bir değişikliktir. Meclisin bir an önce çalışmalarına başlayabilmesini sağlamak için Başkanlık Divanının oluşum sürecinin kısaltılması gerekmekteydi. Çünkï, aday gösterme süresinde Meclis çalışmalarına ara verilip verilmeyeceği konusunda Anayasa ve İçtüzükte açık bir kural yer almamasına karşın genellikle ara verildiğinden, yasama çalışmalarının Başkan seçimi nedeniyle bir süre ertelenmesi ya da kesintiye uğraması söz konusuydu. Gerçekten de, uygulamada yaşanan deneyimler ışı̆̆ında, Meclis Başkanı adayları, Anayasada öngörülen aday gösterme/ olma süresinin son gününde hatta son dakikalarında ortaya çıkmaktayd ${ }^{34}$

1982 Anayasasının 94. maddesi, Başkanın seçimiyle ilgili olarak geçmişte yaşanmış deneyimlere gösterilen tepkilerin izlerini taşımakta ${ }^{35}$ ve Meclis Başkanı seçiminin toplam 20 gün içinde sonuçlandırılmasını kesin olarak kurala bağlamaktaydı.

Son Anayasa değişikliği çerçevesinde Başkan seçimi için verilen Anayasal sürenin 10 güne düşürülmü̧s olması, yasama sürecini hızlandıracak olumlu bir gelişme olarak görüilmelidir.

\footnotetext{
${ }^{33}$ TBMM Tutanak Dergisí, Dönem:21, Yasama Yıl1:4, B.32, 6.12.2001, s. 92-94.

${ }^{34}$ IBA (2001), s. 110.

35 1921 ve 1924 Anayasalarında Başkanın seçimiyle ilgili kurala yer verilmemiştir. 196] Anayasası ise Başkan seçinniyle ilgili süre sınırlaması öngömmemişti. Başkan seçilebilmek için her durumda üye tamsayısının en az salt çoğunluğurun oyuru almak gerekiyordu. Bu uygulama, Meclis Başkanının uzun süre seçilememesine yol açmakta ve yasama sürecinin geç başlamasına neden olmaktaydı. Bkz. İBA (2001), s. 113.
} 


\section{6- Meclis Soruşturması}

Meclis Soruşturması, doğgrudan doğruya yürütme organının denetlenmesine yönelik etkili bir parlamenter denetim aracıdar. Parlamentonun kendi üyeleri arasundan oluşturduğu bir komisyon aracıllğıyla yürütülen soruşturma sonucunda, ilgili bakanın Yüce Divana gönderilip gönderilmeyeceğine yine parlamento karar vermektedir. ${ }^{36}$ Son dönemlerde. Meclis soruşturmasının hukuki niteliği ve jşleyişiyle ilgili yoğun tartışmalar yapılmıştır. Bu tartışmalar, Meclis soruşturnısı komisyonlarının yapısı nedeniyle tarafsızlık ilkesine uygun çalışmalar yürütemeyeceği noktasında ağırık kazanmakta ve çeşitli öneriler geliştirilmekledir. ${ }^{37}$

Parlamento hukukumuzda, Meclis soruşturması yolu, "ceza önsoruşturması" niteliğinde adli/yargısal bir faaliyet olarak düzenlenmiştir. Bu faaliyetin siyasi çatışmalardan hiç etkilenmeden salt hukuk çerçevesinde yürütülmesi gerekir. Ancak, özünde siyasi bir organ olan TBMM`nin istisnai olarak yaptığı bu adli/yargısal faaliyetin salt hukuk çerçevesinde yürütülmesinde bazı güçlükler bulunduğu açıktır. Bu bakımdan. Anayasanın 100. maddesi ile öngörülen düzenleme, Meclis soruşturmasıyla ilģili olarak sırf siyasal tarafsızlık değil, yargısal tarafsızlık j]kesini de benimsemiştir. ${ }^{3 .}$

3.10 .2001 tarihli ve 4709 sayılı Kanunun çerçeve 31 . maddesiyle Meclis soruşturmasıyla ilgili olarak getirilen yeniliklerden en önemlisi, Meclis soruşturmasi komisyonu kurulup kurulmayacağı konusundaki TBMM kararının gizli oylama yöntemine göre alınması zorunluluğudur.

Anayasanın 100. maddesine göre, Meclis soruşturması önergelerinin Başkanlığa verildiği tarihten itibaren bir ay içinde görüşülüp karara bağlanması gerekmektedir. Meclis soruşturmasının açılıp açılmayacă̆ı konusundaki oylamanın gizli oylama yöntemine göre yapılması, Meclis soruşturması kurumunun özüne daha uygun düşmektedir.

4709 sayıl kanunla, Anayasanın 100. maddesine getirilen öteki yenilik ise, Meclis soruşturması komisyonlarınca düzenlenen raporłarın TBMM Genef Kurulunda ele alınmasındaki gecikmeleri ve siyasal istismarları önlemeyi amaçlamaktadır. Konuya ilişkin düzenlemeler daha çok 20. Yasama Döneminde yaşanan bazı deneyimlere tepki niteliği taşımaktadır .

4. Şeref İA (1997). Parlamenter Denetim-Yolları Etkinliği ve Susurluk Örneği, Ankara, Bilgi Yayıncvi,I. Baskı. s.25.

3 [B

${ }^{*}$ Çetin ARSLAN (1999), Yüce Divan Olarak Anayasa Malıkemesi. Ankara. Nobel Yayı1 Dağıtım. s67.

39 Zeki HAFIZOG̈ULLARI \& Asm LjVANELjOĞLU \& Bülent ACAR (1997), Meclis Soruşturmaları Hakkında Düşüinceler-Ü̈ç Örnek. Ankara, Us-A Yayııcılık, s. I0-11 
Meclis soruşturması komisyonlarının Anayasada öngörülen çalışma süresi en fazla dört aydır. Bu süre bittiğinde, Meclis soruşturması komisyonlarının hukuki varlı̆̆ının da sona ereceği kesindir. Anayasanın 100. maddesinde yapılan değişiklik öncesinde de dört aylık çalışma süresi kesindi. Buna karşın, 20 Yasama Döneminde kurulan iki Meclis soruşturması komisyonu bu sürelerini tamamladıkları halde TBMM Başkanlığına raporlarını teslim etmemiştir. 21. Yasama Döneminde bu komisyonlar yeniden kurulmuştur. ${ }^{40}$ Bu deneyimlere tepki olarak son Anayasa deģişikliği sırasında Anayasanın 100. maddesine şu cümle eklenmiştir: "Bu süre içinde raporun Türkiye Büyük Millet Meclisi Başkanlığına teslimi zorunludur." Aslında, bu cümle eklenmeden önce de Meclis soruşturması komisyonları için raporun, dört aylık süre içerisinde Başkanlığa teslim ediImesi Anayasal bir yükümlülüktii. Yeni eklenen bu cümle ile, Meclis soruşturması komisyonlarının bu yükümlügüne vurgu yapılmış olmakta ancak, 20. Yasama Döneminde yaşandığı gibi süresinde raporunu vermeyen komisyonlar için ne yapılması gerektiği konusu açıklığa kavuşturulmamaktadır.

Değişiklik öncesi hükme göre, Meclis soruşturması raporları, TBMM Gündeminin "Meclis Soruşturması Raporları" adını taşıyan özel bir kısmına alınmakta ve ilgili Komisyonun Genel Kurulda hazır bulunmaması durumunda görüşmelere başlanmadığından ${ }^{41}$ Meclis soruşturması raporlarının ivedilikle görüşüleceği kurahı uygulamada işletilmemekteydi. ${ }^{42}$

40) 20. Yasama Döneminde süresini tamamladığ halde raporların vermeyen kornisyonlar şunlardır:

- (9/18) Esas Numaralı İstanbul- Kurtköy Havaalanı ihalesi ile ilgili olarak eski Başbakan Mesut Yılmaz hakkında kurulan Meclis Soruşturması Komisyonu

- (9/19) Esas Numaralı Karadeniz Sahil Yolu ile ilgili olarak Bayındtrlık ve İskan eski Bakanı Yaşar Topçu hakkında kurulan Meclis Soruşturması Komisyonı

Bu komisyonların kurulmasına dayanak oluşturan Meclis soruşturması önergeleri, 21.

Yasama Döneminin başında Genel Kurulda yeniden görüşülmulı̧ ve 23.11. 1999 tarihli 23. Birleşimde alınan 656 Numaralı Karar ile ayn konularda yeniden komisyonlar kurulmuştur. Bkz. Resmi Gazete, 2.12.1999, Sayı:23894.

41 TBMM Genel Kurulunda komisyonların temsili konusu, TBMM Içtüzüiöünün 45 . maddesinde gösterilmiştir. Anılan madde, görüşülecek işlerle ilgili komisyonun her durumda Genel Kurulda hazır bulunmasın gerektirecek bir zorunluluk öngörmemiştir. Üstelik, TBMM Iç̧üzügüunuủn başka bir herhangi bir maddesinde de bu yönde bałlayıcı bir kural yoknur. Oysa, Genel Kurulda hükümetin temsilini düzenleyen 62. madde, her görüşmenin başından sonuna kadar hükümetin hazır bulunmasın zorunlu kılmaktadır. Ayrıca, görüşmelerin başında hükümetin temsil edilmemesi durumunda o konudaki görüşmelerin bir defalık gelecek birleşime ertelenmesi biçiminde bir yaptınm öngörmektedir.

Görüşmelerin başında komisyonun Genel Kurulda temsilini zonunlu kılan açık bir yazılı kural bulunmamasına karşın. sözü edilen uygulama, gựçlü bir parlamento teamúlỉ olarak yürürlüktedir.

Bkz. IBA (2001), s. 140-141.

42 Örneğin. 19. Yasama Döneminde kurulan hayali ihracat iddiaları konusunda kurulan (9/22) esas numaralı Meclis Soruşturması Komisyonu tarafından hazırlanan Rapor (S.Sayıs1:779); ilk olarak 7.3.1995 tarihli 82. Birieşim Gindeminde yer aldığ halde, 
Yeni düzenleme ile Meclis soruşturması raporları, Meclis Başkanlığ na verildiği taribten itibaren 10 gìn içinde dağıtılmak zorunda: dağıtım tarihinden itibaren 10 gün içinde ise Genel Kurulda görisşiilmek zorundadır. Böylece. Meclis soruşturması raporlarının Başkanlığa verildiği tarihten itibaren 20 gün içinde görüşülmesi zorunluluğu ortaya çımaktadır.

Bununla birlikte, son Anayasa değişiklikleri sırasında, Meclis soruşturması komisyonlarmın siyasal etkilerden uzak biçimde tarafsızlık ilkesine göre çalışabilmesi için yapısal bir değişikliğe gidilmesi gerektiği yönündeki eleştiri ve tartı̧̧malara yanıt oluşturacak yeni bir düzenlemeye gidilmemiş̧̧ir.

Son Anayasa değiş̧iklikleri sırasında Anayasanın 100. maddesinde Meclis soruşturmasıyla ilgili olarak gerçekleştirilen değģ̧iklikler, Meclis soruşturması kurumunun daha etkili bir parlamenter denetim aracı olarak işlev görme yeteneğini artıracak olumlu adımlar olarak görülmelidir.

\section{SONUÇ}

3.10.2001 tarihli ve 4709 numaralı Türkiye Cumhuriyeti Anilyasasmın Bazı Maddelerinin Değiştirilmesi Hakkmda Kanun, son dönem parlamento tarihimizin en kapsaml Anayasa değişikliğidir. Söz konusu Anayasa değişikliği, sivil-siyasal girişimler sonucu olabildiğince geniş bir uzlaşma Anayasanın 89. maddesinde gerçekleştirilen ve Cumhurbaşkanma kanunlar: kısmen bir daha görüşülmek üzere Meclise geri gönderme yetkisi veren değişiklik bazı bakımlardan hukuki yorum farklılıklarına elverişli biçimde düzenlenmiş olmakla birlikte, yasamanın işleyişinden kaynaklanan zaman kaybını gidermeyi amaçlayan olumlu bir yeniliktir. Parlamento hukuku açısından daha fazla önem taşıyan Meclis soruşturması, TBMM başkanının seçim süreci, seçim kanunlarının yürürlüğü, af ilan gibi konulardaki yeni düzenlemeler. yasama organının kuruluş ve işleyişini hızlandırıcı etki doğurabilecek özelliktedir.

Bu irdelemeler ışığında, TBMM'nin başarılı çalışmalarının ỉrünü olan son Anayasa değişiklikleri, parlamentonun daha verimli ve etken biçimde işleyişine katkıda bulunacak olumlu Anayasal adımlar olarak değerlendirilmelidir. 


\section{KAYNAKÇA}

Y11:3.

- Anayasa Komisyonu Raporu, S. Sayısı: 737, Dönem:21, Yasama

- Anayasa Komisyonu Raporu, S.Sayıs1: 753, Dönem:21, Yasama Y1li:4

- Anayasa Mahkemesi Kararlar Dergisi, E.199127, K.1991/50, 12.12. 1991, C.27/2, s.681-703.

- Anayasa Mahkemesi Kararlar Dergisi, E.1992/26, K. 1992/48, 17.9 .1992 , C.28, s.548.

- ARSLAN,Çetin (1999) Yüce Divan Olarak Anayasa Mahkemesi, Ankara, Nobel Yayın Dağıtım, 1. Baskı.

- BAKIRCI, Fahri (2000), TBMM'nin Çalışma Yöntemi, Ankara, İmge Kitabevi, 1. Bask1.

- Erdoğan TEZİÇ ve Işın ÇELEBİ ile Söyleşi, Cumhuriyet, 21.10.2001.

- EROĞUL, Cem (1974), Anayasayı Değiştirme Sorunu, Ankara, AÜSBF Yayın No:871.

- HAFIZOĞULLARI, Zeki (1997) \& Asım LIVANELtoĞLU\& Bülent ACAR, Meclis Soruşturmaları Üzerine Diişünceler Ü O̧ Örnek, Ankara, Us-A Yayıncilık.

- IBA, Seref (1997), Parlamenter Denetim-Yolları, Etkinliği ve Susurluk Örneği, Ankara, Bilgi Yayınevi, 1. Baskı.

- İBA, Şeref (2001), Türkiye'de Meclis Başkanlı̆gı ve Başkanlık Divanı, Ankara, Nobel Yayın Dağıtım, 1. Baskı.

- ONAR, Erdal (1993), 1982 Anayasasında Anayasayı Deģiştirme Sorunu, Ankara.

- ÖZBUDUN, Ergun (1979), "Parlamento Kararları ve Yasama Meclislerinin İçtüzükleri", A.U. Hukuk Fakültesi Dergisi, C.XXXVI., Say1: 1-4, s.3-26.

- Resmi Gazete, (çeşitli sayılar)

- TBMM İçtüzüiğả, Türkiye Cumhuriyeti Anayasası ve Türkiye Büyük Millet Meçisi İçtüzüŭgu,Ankara, 2001, TBMM Basımevi.

- TBMM Tutanak Dergisi, (çeşitli birleşimler)

- TEZİç, Erdoğan (1980), Türk Parlamento Hukukunun Kaynakları ve İlgili Anayasa Mahkemesi Kararları, Ístanbul; Fakülteler Matbaası. 